\title{
SETTING UP CAMP AT THE GREAT INSTRUCTIONAL DIVIDE EDUCATING BEGINNING HISTORY TEACHERS
}

\author{
Robert Bain \\ Jeffrey Mirel \\ University of Michigan
}

This article sketches out a comprehensive approach for preparing history teachers. It argues that grounding in historical content knowledge is necessary for success in the classroom, but such grounding is not enough to ensure that success. For beginning teachers, the problem is not merely acquiring content knowledge but acquiring it in ways that facilitate teaching subjects to young people of varied backgrounds and abilities. In short, teachers need to understand content in the context of teaching, meaning prospective history teachers must have a robust understanding of history's details, ways in which historians acquire and structure those details, and how teachers can make the subject accessible and worth knowing for students. This approach demands that teachers also know how their students understand history and the assumptions they make about historical events and developments. Finally, prospective teachers need to know how to offer content-rich, engaging instruction within a standards-based, high-stakes testing context.

Keywords: social studies education; teachers' knowledge and beliefs; theories of teacher education

In 1840 , at the end of his 4 th year as the secretary of the Massachusetts Board of Education, Horace Mann used his annual report to examine "the qualifications essential to those who undertake the momentous task of training the children of the State" (Cremin, 1957, p. 44). The first two qualifications that he identified were knowledge of subject matter and mastery of the "art of teaching," by which he meant "a knowledge of methods and processes" for teaching school subjects (Cremin, 1957, pp. 45-48). These qualifications are as relevant to beginning teachers today as they were to their counterparts in the 19th century. Unfortunately, despite more than a century and a half of work by a multitude of scholars, thinkers, practitioners, and visionaries, realizing the goal of preparing teachers who know their subjects and how to teach them seems as troublesome and elusive today as it was when Mann penned his Fourth Annual Report.

The problem as we see it is that educational leaders, since the time of Horace Mann, routinely have treated content knowledge and methods as separate albeit related areas of study, research, and teacher preparation. At its best, teacher education programs have viewed this approach as an additive model. Preservice teachers would enter professional education programs with a reasonable amount of subject matter knowledge and then gain expertise in how to teach that knowledge to their students. At its worst, the dichotomy of subject matter and methods led to a compartmentalized model

\footnotetext{
Authors' Note: We would like to thank Anne-Lise Halvorsen, Lauren McArthur, and Tamara Shreiner for their insightful comments on this article. Two anonymous reviewers who are contributors to this issue also helped us sharpen our argument.
}

Journal of Teacher Education, Vol. 57, No. 3, May/June 2006 212-219

DOI: $10.1177 / 0022487105285892$

(C) 2006 by the American Association of Colleges for Teacher Education 
in which experts on both sides of the divide paid little attention to one another. In this case, subject matter specialists disdained the need for mastering teaching skills, and experts in methods abstracted content to such a degree as to render disciplinary knowledge almost irrelevant to teaching practice. Throughout the 20th century, teacher education programs employed variations of both the additive and compartmentalized models. Consequently, most efforts at reforming teacher education focused on privileging content or methods, with these efforts consistently failing to bridge the divide.

Although we strongly align ourselves with scholars who argue for the primacy of academic content-teachers cannot teach what they do not know-the knowledge needed to teach challenging subject matter is more complicated than simply demanding that prospective teachers have majors in their subject areas. For beginning teachers, the problem is not merely acquiring content knowledge but acquiring it in ways that facilitate teaching subjects to young people of varied backgrounds and abilities. In short, teachers need to understand content in the context of teaching. As John Dewey observed in The Child and the Curriculum, the teacher "is not concerned with subject-matter as such, but with subject-matter as a related factor in a total growing experience" (Archambault, 1966, p. 352). Or as Lee Shulman (1986) argued, teachers' content knowledge must also include "ways of representing and formulating the subject that make it comprehensible to others" (p. 9).

The problem before us, then, is not simply adding more content knowledge in teacher education programs, although more content is surely necessary, but rather to transform the knowledge prospective teachers learn in ways that make it useful for the challenges of teaching. ${ }^{1}$ This article examines that process as it relates to the preparation of history teachers.

\section{ACQUIRING ROBUST CONTENT AND DISCI- PLINARY KNOWLEDGE IN HISTORY}

Beginning teachers must be steeped in the disciplines they teach, and having an undergraduate major is a reasonable proxy for assuming that students have such knowledge. How- ever, we maintain that unless these majors are configured to ensure students understand what Jerome Bruner (1960) called the fundamental structure of the discipline, new teachers will enter their own classrooms without sufficient knowledge to teach their subjects well. Such a focus does not privilege process at the expense of facts but rather, rests on the understanding that disciplines organize facts in ways that give them meaning, making these facts more memorable because they are more meaningful.

Detail is important in history, but as Bruner (1960) has explained, "Unless detail is placed into a structured pattern, it is rapidly forgotten" (p. 24). Good history, whether in scholarly monographs or eighth-grade classrooms, organizes factual detail in meaningful ways using narrative, historiographic problems, and spatial-temporal or causal schemes. However, the features that give meaning to historical detail are often invisible to students learning history, whether sitting in a fourth-grade classroom or in an undergraduate survey course. When done effectively, history sweeps students up in engaging stories, powerful problems, or important events, often leaving students unaware of the historian's or history teacher's role in selecting, organizing, analyzing, and structuring the details. Future history teachers, however, must understand how historians frame historical problems, select and organize factual details, analyze and construct historical stories, and as important, how to present these "invisible" structures to their students in meaningful ways. In short, history majors seeking to become history teachers must be conversant in historiography, looking carefully and critically at ways various historians have organized and created historical understanding. Without such understanding, history for most prospective teachers is, at best, a story well told and at worst, merely a collection of facts.

Unfortunately, universities often leave courses on the nature of disciplines to graduate study or late in the program for undergraduate majors. While this might make sense for students going on to advanced study - though we question that approach as well-it is not reasonable for students preparing to teach. A robust 
understanding of history's details, the ways historians acquire and structure those details, enables teachers to render the subject accessible and worth knowing for students (Bruner, 1960). In other words, this deep knowledge of content and discipline is necessary for teachers to create experiences that help students learn the content.

\section{USING DISCIPLINARY KNOWLEDGE TO CONFIGURE PEDAGOGY}

Prospective teachers, like novice historians, must know the structure of their discipline. But unlike historians, teachers are not using that knowledge to make advances in the field of history. Rather, teachers have to use that knowledge to help others master content, and often they must do so in conditions that do not easily facilitate learning challenging and complex material and often with learners unwilling or initially unable to take up such work. Beyond knowing the content, then, beginning teachers must be able to use the content to configure classrooms for student learning.

Teacher educators cannot do this simply by adding teaching techniques to content but rather, must help prospective teachers use the epistemology of the field to (a) probe students' understanding of the content, (b) organize mandated curriculum, and (c) construct environments and experiences that help students move from initial understandings to more sophisticated knowledge of history. Beginning teachers, therefore, need experiences using their content knowledge to assess students' knowledge of history. For example, new history teachers should be able to take their understanding of the causes and consequences of the American Revolution, including their familiarity with historiographic debates about the revolutionary period, to probe what their students know about the period and the theories the students hold about such critical ideas as revolution and change. In addition to students' preinstructional ideas about life in colonial America, teachers might try to understand what students think promotes rebellion. What assumptions and theories do students have about the role of ideas, economic restrictions, or other factors in pro- moting change? What theories do students have about what makes something historically significant? What preinstructional conceptions do students have concerning agency? What actors are visible and invisible in the stories students tell of the past?

To help develop this capacity for considering students' thinking, prospective history teachers should become familiar with a growing body of literature describing ways that students' preinstructional ideas about history might influence what they learn, including, for example, studies by Bain (2000, 2005); Barton (1997); Epstein (2000); Lee (2005); Leinhardt, Stainton, Virji, and Odoroff (1994); Levstik (2000); Seixas (1994); VanSledright (2002), and Wineburg (2001). The work of Wineburg, Levstik, Lee, Seixas, Barton, or Bain can alert prospective teachers to problems their students might have in working with primary sources, determining significance, creating context, or understanding the "pastness" of the past. Although not predictive of how students will think, these studies focus prospective teachers on students' thinking while "doing" history, sharpening teachers' eyes to the situation in which they will act-the classroom.

The beginning teacher, therefore, should understand the value of uncovering students' history-specific knowledge of events under study and the ideas that give power and meaning to historical details. Furthermore, prospective teachers should become familiar with ways to design formal and informal assessments to identify their students' understanding of history. In short, beginning teachers must have knowledge of and experience in using content to determine the facts that students know, the meaning students give to these facts, and the theories students have about history, agency, significance, cause and effect, and last, what goes into the construction of plausible historical accounts.

We are not saying that beginning teachers must become psychologists probing student thinking to uncover the dynamics of learners' cognition. Rather, new teachers must learn to make the effort to "see" their students' historical thinking and then use what they learn to shape instruction. This does not mean, as is typ- 
ically defined, that teachers should "dumb" down the curriculum or pander to the interests of students but rather, that teachers should be capable of discovering "where their students are" to bring them to the deeper and richer understanding of history that we seek.

\section{REIMAGINING STANDARDS AND TEXT- BOOKS FOR EFFECTIVE PEDAGOGY}

Beginning teachers also must be able to employ their content and disciplinary knowledge to organize curriculum and design learning activities. In this era of mandated standards and heavy reliance on history textbooks, we often neglect the vital role that teachers must play in thoughtfully organizing standards and textbooks for instruction. Standards and textbooks are not curriculum. However, for teachers without rich content knowledge and practice in using disciplinary knowledge to create instruction from standards and texts, the standards and textbooks, unfortunately, become the curriculum. Given that, new teachers must have experience and skill in bringing disciplinary understanding to standards and textbooks.

Consider the ways content arrives at the beginning teacher's classroom door, often in the form of behavioral objectives listing what students should be able to do or in textbooks thick as encyclopedias, filled with dry descriptions of even the most dramatic historical events, and overflowing with visuals that are supposed to breathe life into this otherwise barren field (Apple \& Christian-Smith, 1991; Ravitch, 2004). From a disciplinary stance, there is little in standards or texts that captures the meaning and excitement of studying history. For example, most state standards and textbooks typically leave out the very questions or debates that stimulate historical inquiry and lead to advances in historical knowledge in the first place. The questions in history textbooks routinely come after students have studied the content and are used as vehicles to assess learning, not to drive inquiry or to organize study (Bain, 2005, in press). Beginning teachers, therefore, must be able to use their understanding of historiographic questions to restructure standards and texts with regard to the fundamental problems and enduring questions that engage us in studying history.

Furthermore, history is a discipline that is grounded in evidence, shaped by what historian Carlo Ginzburg (1989) has called the "evidentiary paradigm." Yet in schools, students regularly trek across vast expanses in textbooks, films, worksheets, and lectures and rarely stumble over the evidence that supports the narratives they are encountering. Using their understanding of the discipline, teachers should see the necessity of bringing historical evidence to historical study and of embedding a variety of historical sources-primary and secondaryinto the classroom experience. Initially, new teachers should have the knowledge and capacity to identify one or two areas of the history curriculum that they know well enough to use as models for explaining how historians have derived and assessed the evidence they use in re-creating the past for historical examination. They should be able to use this knowledge strategically to select and edit sources for their students to use as evidence when studying those areas. Moreover, we expect that new teachers will understand some of the challenges students face in working with texts and evidence and have some history-specific strategies to help their students understand and assess the variety of evidentiary material.

Transforming classroom materials in this way will enable beginning teachers to organize and give multiple meaning to historical details. School history-particularly as represented in textbooks-relies almost exclusively on chronological patterns of organization, minimizing or obscuring other more powerful ways to make sense of historical facts. We are not saying chronology is insignificant-history is the study of change over time. But most students experience historical study as just "one damned thing after another," whereas historians make meaningful connections among facts, thus, yielding more powerful analyses than simply identifying when events occurred.

For example, the year 1492 is an important date in both American and world history classes. But if the date is just used to establish a chronology leading to the eventual emergence 
of the United States or the rise of the West, it will simply stand out as one more date, albeit a significant one, that students need to memorize. However, if the date is used to group events such as (a) the Spanish Inquisition, (b) the Reconquesta, (c) Columbus's first voyage and the beginning of the conquest of Native peoples, and (d) the publication of the first book to study and define the grammar of a European language, Antonio de Nebrija's The Art of the Castilian Language, teachers, like historians, might examine these events in relation to emerging nationalism, thus, giving the above facts meaning grounded in the context and not just the year. They would also be providing students with a powerful tool to assess similar attempts throughout history to forge nationstates based on a common ethnicity, religion, and/or language.

Furthermore, the epistemological approach to history encourages teachers and students to consider the date of 1492 itself by asking how different historians and people viewed it, what it signifies, and how that signification has changed with time (Bain, 2005; Bushman, 1992). Such a stance opens the study of history to the story of peoples often ignored, such as Native Americans, Moors, and Jews, as well as more "traditional" interpretations. And the historiographic approach offers teachers and students the opportunity to situate parochial histories of Europeans and Native peoples against a larger backdrop of shifting global movements and transformations (Crosby, 1997). In short, understanding the structure of the discipline of history helps teachers move beyond mere chronology to develop multiple ways of representing historical facts and events.

It is not too much to ask that beginning history teachers be able to take an era or problem in history and consider two or three historically appropriate ways to organize it for learners, analyzing and discussing the strengths and weaknesses of each. Then, after teaching the content, beginning teachers should be able to analyze what students learned and the obstacles faced in learning by analyzing the pedagogical strengths and weaknesses of the approach they took teaching specific history content to specific history students.

Again, without deep and robust understanding of history, beginning teachers could not engage in such instructional work. However, without experiences in an epistemologically structured design of learning, including analyses of students' historical understanding and thinking, beginning teachers still might not be able to use fully their historical knowledge for history teaching.

Finally, novice teachers should learn how other history teachers have successfully taught history and be able to assess the evidence offered for that success. Too often beginning teachers, like veteran teachers, simply rely on lesson plans for their guides in teaching history. These recipes for instruction typically fail beginning teachers because they never show the result of following the recipe (i.e., students' learning) or the mess the "chef" made in the kitchen. Beginning teachers need to learn how to locate and read strong examples of instructional practice such as Holt's (1995) writing about teaching history in college or Bain's (2000, 2005) in high school or VanSledright's (2002) in elementary school. Just as historians read the works of the great practitioners of their craft to identify and criticize ways to frame historical problems, build historical cases, and represent historical knowledge, beginning teachers also need to develop familiarity with history-specific scholarship on teaching and learning. By examining the specific problems in teaching and learning history, beginning teachers will be able to join and contribute to the ongoing professional conversation about history instruction.

\section{CONCLUSION}

The obvious criticism of the program we are recommending is that we are expecting beginning teachers to have the content knowledge of history Ph.D.s and the skill of master history teachers with 20 years of experience. Such criticism misses the point. We are not suggesting that new history teachers have expert grounding in all the areas we have discussed in this arti- 
cle. What we are saying is that they need more than a breadth of understanding of world and U.S history in their training. In addition to broad content knowledge, we think that at a minimum beginning teachers should have sufficient understanding of and experience in using disciplinary and pedagogical knowledge dynamically to design and enact history instruction about one or two key events or periods (such as the Civil War era or the rise of fascism and communism in the post-World War I years). New teachers should be able to use their knowledge of a few selected historical periods to assess students and develop instruction grounded in the discipline in the ways we have outlined. These "expert units" will then serve as the models for how to approach the other areas of history that these teachers must teach.

We believe that this sound foundation then will foster effective professional growth. In other words, new teachers starting with small but rich pedagogical successes will be able to build on their experiences and expand the range of their knowledge and teaching skills into new areas of history. To paraphrase Dewey, learning to teach is a total-growing experience and teachers, like all professionals, should continually learn on the job. This process will be easier and more productive if they have sound foundational knowledge.

Where to begin? We might start by redefining the additive or compartmentalized relationship between learning content and learning how to teach by setting up our programs in the great divide between content and pedagogy. As teacher educators, we could begin by asking how our courses provide prospective teachers opportunities to learn teaching strategies and whether they also offer chances to acquire and use an understanding of the structure of the discipline to think about standards, curriculum, textbooks, and learners' discipline-specific thinking. Although we suspect most instructional approaches to preparing teachers stress the use of the discipline's "big ideas" or "essential questions," we should remember that prospective teachers have little experience with such epistemological questions (McDiarmid \& Vinten-Johansen, 2000; Wilson \& Wineburg,
1988). Hence, they need regular opportunities to identify the discipline's critical problems and ideas-most likely beginning with the very history courses they have taken. We could have prospective history teachers use their methods or educational psychology classes to reframe the notes from their history classes, looking for the underlying ideas and theories about cause and effect, significance, agency, or narrative that structured both the course and their learning. Then, the preservice teachers might apply those same ideas to instructional materials, such as state standards and textbooks, or design ways to probe student thinking of these issues.

Such activities at the intersection of content and pedagogy could populate a variety of courses from foundations to methods to educational psychology. This would require teacher educators to expand the assigned readings and pedagogical practices of such courses to include historiographic articles, studies of students' thinking historically, and classroom examples of history teachers' employing epistemically grounded pedagogy; and it would require prospective teachers to employ these ideas in designing, enacting, reflecting, and modifying instruction situated at these intersections.

Of course, this makes two critical assumptions about the preservice teachers entering teacher education programs and the teacher educators teaching in the programs. First, incoming students need a well-stocked portfolio of content knowledge to "make pedagogical." Second, teacher educators must have an even more fluid and flexible depth of disciplinary knowledge to assist prospective teachers as they transform their understandings. How much and what type of content knowledge is needed? Here the field needs more scholarship to define what makes usable knowledge for both history teachers and history teacher educators themselves.

Admittedly, however, even the best teacher education programs imaginable will not be enough to provide the kind of sustained support of the "well-started" teacher we envision. To continually develop deeper disciplinary and pedagogical knowledge, both novice and experienced teachers must have access to high-quality, ongoing profes- 
sional development programs. Indeed, we believe that this and other institutional supports are essential for improving the quality of instruction in every content area, not just history.

We realize the difficulty of preparing beginning teachers with the knowledge and skills described here and recognize the obstacles that stand in the way of creating truly effective professional development programs for practicing teachers. But we also are certain that if we do not make this effort, if history education programs do not move in the direction that we have described, educators may well spend another century and a half repeating the fruitless struggle between content and methods that has characterized curriculum history in this country.

\section{NOTE}

1. For example, we think the recent efforts of the U.S. Department of Education (2004) to "raise student achievement by improving teachers knowledge, understanding, and appreciation of American history" (para. 1) have captured only a piece of what history teachers need to improve students' knowledge, understanding, and appreciation of American history.

\section{REFERENCES}

Apple, M., \& Christian-Smith, L. (1991). The politics of the textbook. New York: Routledge.

Archambault, R. D. (1966). Dewey on education: Appraisals. New York: Random House.

Bain, R. B. (2000). Into the breach: Using research and theory to shape history instruction. In P. Stearns, P. Seixas, \& S. Wineburg (Eds.), Knowing, teaching and learning history: National and international perspectives (pp. 331-353). New York: New York University Press.

Bain, R. B. (2005). "They thought the world was flat?": HPL principles in teaching high school history. In J. Bransford \& M.S. Donovan (Eds.), How students learn: History, mathematics, and science in the classroom (pp. 179-214). Washington, DC: National Academies Press.

Bain, R. B. (in press). Rounding up unusual suspects: Facing the authority hidden in history textbooks and teachers. Teachers College Record.

Barton, K. C. (1997). "I just kinda know": Elementary students' ideas about historical evidence. Theory and Research in Social Education, 25(4), 407-430.

Bruner, J.S. (1960). The process of education. Cambridge, MA: Harvard University Press.

Bushman, C. (1992). America discovers Columbus: How an Italian explorer became an American hero. Hanover, $\mathrm{NH}$ : University Press of New England.
Cremin, L. A. (Ed.). (1957). The republic and the school: Horace Mann and the education of free men. New York: Teachers College Press.

Crosby, A. W. (1997). The measure of reality quantification and Western society, 1250-1600. Cambridge, UK: Cambridge University Press.

Epstein, T. (2000). Adolescents' perspectives on racial diversity in U.S. history: Case studies from an urban classroom. American Educational Research Journal, 37(1), 185-214.

Ginzburg, C. (1989). Clues: Roots of an evidential paradigm. In Clues, myth, and the historical method (pp. 96-125, 200-213). Baltimore: Johns Hopkins University Press.

Holt, T. C. (1995). Historically: Narrative, imagination, and understanding. New York: College Entrance Examination Board.

Lee, P. J. (2005). Putting principles into practice: Understanding history. In J. Bransford \& M. S. Donovan (Eds.), How students learn history in the classroom (pp. 31-77). Washington, DC: National Academy of Sciences.

Leinhardt, G., Stainton, C., Virji, S., \& Odoroff, E. (1994). Learning to reason in history: Mindlessness to mindfulness. In M. Carretero \& J. F. Voss (Eds.), Cognitive and instructional processes in history and the social sciences (pp. 131-158). Hillsdale, NJ: Lawrence Erlbaum.

Levstik, L. S. (2000). Articulating the silences: Teachers' and adolescents' conceptions of historical significance. In P. Stearns, P. Seixas, \& S. Wineburg (Eds.), Knowing, teaching and learning history: National and international perspectives (pp. 284-305). New York: New York University Press.

McDiarmid, G. W., \& Vinten-Johansen, P. (2000). A catwalk across the great divide: Redesigning the history teaching methods course. In P. Stearns, P. Seixas, \& S. Wineburg (Eds.), Knowing, teaching and learning history: National and international perspectives (pp. 156-177). New York: New York University Press.

Ravitch, D. (2004). A consumer's guide to high school history textbooks. Washington, DC: Thomas B. Fordham Institute.

Seixas, P. (1994). Students' understanding of historical significance. Theory and Research in Social Education, 22, 281304.

Shulman, L. (1986). Those who understand: Knowledge growth in teaching. Educational Researcher, 15(2), 4-14.

U.S. Department of Education. (2004). Teaching American history grant program. Retrieved December 15, 2004, from http: / / www.ed.gov/programs/teachinghistory / index.html

VanSledright, B. (2002). In search of America's past: Learning to read history in elementary school. New York: Teachers College Press.

Wilson, S. M., \& Wineburg, S. (1988). Peering at history through different lenses: The role of disciplinary perspectives in teaching history. Teachers College Record, 84, 525-539. 
Wineburg, S. (2001). Historical thinking and other unnatural acts: Charting the future of teaching the past. Philadelphia: Temple University Press.

Robert Bain is associate professor of history and social science education in educational studies at the University of Michigan. He taught high school history and social studies for 26 years in the Cleveland, Ohio, area. He earned his Ph.D. in history from Case Western Reserve University. His research investigates the relationships among history as a disciplinary way of knowing, learning, and teaching. Current research projects include the design and use of history-specific technology for students engaged in historical inquiry and an investigation of history-specific preservice and professional development. His recent publications include the chapter "They Thought the World Was Flat?' Principles in Teaching High School History" in How
Students Learn: History, Math and Science in the Classroom (National Academy Press, 2005). In 2000, Carnegie Foundation selected him as a Carnegie scholar in the Carnegie Academy of Teaching and Learning.

Jeffrey Mirel is professor of educational studies, professor of history, and a faculty associate in the Center for Russian and East European Studies at the University of Michigan. His major research interests are the history of urban schooling and curriculum policy in the United States. He is the author of The Rise and Fall of an Urban School System: Detroit, 1907-81 (University of Michigan Press, 1999, 2nd ed.) and the coauthor, with David Angus, of The Failed Promise of the American High School, 1890-1995 (Teachers College Press, 1999). He is currently writing a book on education and the Americanization of immigrants in the first half of the 20th century. 